\title{
Training Need Perception of Beekeepers with Respect to the Scientific Beekeeping Practices in Jammu Province
}

\author{
Yogesh Kumar ${ }^{1 *}$, Kaneez Fatima ${ }^{1}$, Rajinder Peshin², Bashir A Rather ${ }^{1}$, \\ Sushil Kumar ${ }^{2}$ and Mehrajuddin Sofi ${ }^{1}$ \\ ${ }^{1}$ High Mountain Arid Agriculture Research Institute (HMAARI), \\ SKUAST-K, Leh Ladakh, India \\ ${ }^{2}$ Division of Extension Education, SKUAST Jammu, India \\ *Corresponding author
}

\section{A B S T R A C T}

\begin{tabular}{|l|}
\hline Ke y w o r d s \\
Beekeepers, \\
Beekeeping \\
Practices \\
\hline Article Info \\
\hline $\begin{array}{l}\text { Accepted: } \\
\text { 20 August 2020 } \\
\text { Available Online: } \\
\text { 10 September } 2020\end{array}$ \\
\hline
\end{tabular}

\section{Keywords}

Beekeepers, Beekeeping Practices

Article Info

Accepted:

Available Online:
The study was undertaken to assess the training needs of beekeepers of Jammu region in order to improve their technical knowhow for increasing honey production and to overcome their various constraints. Four districts were purposively selected for the study which include Jammu, Kathua, Rajouri and Ramban, as the maximum number of the beekeepers fall in these four districts in the Jammu province. The study revealed the highest perception of beekeepers about training needs in different production and protection areas which include honey testing, queen rearing, method of wax production and management of honey bee pests and diseases. The pooled data of the study revealed that training in honey testing was perceived as most important area on the basis of the training need index calculated for the practice as cent per cent of the beekeepers responded positively for requirement of this training followed by queen rearing $(90.41 \%)$, method of wax production $(89.21 \%)$, management of insect pests $(88.69 \%)$, honey processing $(85.95 \%)$ and giving queen to queen less bees $(84.41 \%)$. The other bee keeping practices like honey extraction, bee flora, division of boxes and winter packing were also perceived as important trainings by the respondent beekeepers as observed by the training need index. However, the feeding method $(70.71 \%)$, uniting of boxes $(70.37 \%)$ and sugar feeding (67.12) were perceived less important amongst the training needs of the respondent beekeepers.

\section{Introduction}

Beekeeping has established itself as an economic activity and a commercial enterprise in several countries which benefit their agricultural and horticultural development besides providing manufacturing of valuable nutritive and medicinal products.
It has a great potential for self-help of the rural people of the country. It provides the employment, new sources of income generation, food and nutritional security and improves rural economy. Several valuable contributions to the art and science of beekeeping made by beekeepers and agricultural scientists have led to beekeeping 
as an important component of integrated farming system in agriculture. Beekeeping is an appropriate technology because it has a very low scale and requires little money to begin with. It also contributes to the upliftment of rural masses by way of employment generation and as a subsidiary occupation to supplement their income. In Jammu and Kashmir also, efforts are made to raise the economic and social status of the weaker sections of the rural societies, who are below the subsistence level.

Beekeeping being forest based in the state of $\mathrm{J} \& \mathrm{~K}$ offers great potential as the net forest area covers an area of about six lakh and fifty eight thousand hectare (Anonymous, 1999). The commercial apiculture in Jammu region has been largely promoted in near past by the State Agriculture Department, Krishi Vigyan Kendras and other non-governmental organizations. A separate apiculture wing in the State Agriculture Department is functional since 1973 for promotion of commercial apiculture. In Jammu province alone Agriculture department produced 589 metric tons honey in 2018 (Anonymous, 2018). However, a number of factors affect the growth and development of the beekeeping industry which include climatic conditions, training, extension and research, improved methods of management, queen rearing, pest and disease management, improved honey harvesting, processing, marketing and injudicious use of pesticides.

In this modern age, training of beekeeping is considered as one of the most important nonmonetary inputs in all the aspects of development programmes. The training of beekeepers in beekeeping practices is considered as an indispensable instrument, for rapid transfer of scientific beekeeping technology in modernizing the traditional beekeeping practices and improving the economic condition of beekeepers. That is why the present study was undertaken to identify the perception of training needs of beekeepers in important thrust areas of bee keeping in Jammu region.

\section{Materials and Methods}

The present study was conducted in the Jammu region of J\&K state during 2016 and 2017. Four district were purposively selected for the study as the maximum number of the beekeepers fall in these four districts in the Jammu province which include Jammu, Kathua, Rajouri and Ramban,. They were selected based on the census of beekeepers carried out by department of Agriculture during 2011. A registered list of beekeepers of the selected districts was obtained and accordingly the number of beekeepers was selected randomly in each district, based on the proportionate random sampling method. A total sample of 210 beekeepers was selected in all the four districts which include 126 from Ramban, 22 from Rajouri, 43 from Kathua and 19 from Jammu. The selected beekeepers were interviewed on the basis of a well structured questionnaire. A schedule was also developed to know perception of training need of beekeepers which was measured on 3 point continuum i.e. mostly needed', 'needed', 'not needed', with a score of 3,2 and 1 respectively. Accordingly training need intensity was worked out by using the following method:

Training need index $=$ Actual score obtained by a beekeeper Maximum possible score

Ranks were also assigned to all the bee keeping practices on the basis of training need index (Soumya and Podikunju, 2017).

On the basis of training need index the perception of training need for different beekeeping practices was categorised as: 


\begin{tabular}{|c|c|}
\hline $\begin{array}{c}\text { Training need index } \\
\text { (No.) }\end{array}$ & Category \\
\hline $\mathbf{8 0 - 1 0 0}$ & Most important \\
\hline 60-80 & Important \\
\hline Below 60 & Less important \\
\hline
\end{tabular}

\section{Results and Discussion}

The results presented in Table 1 revealed the perception of training need of farmers of Kathua district. Trainings on honey testing, method of wax production, giving queen to queen less bees, formula of feeding and management of insect pests were observed the most important areas in which beekeepers require training in the district as observed on the basis of the calculated training need index.

The data revealed that almost cent per cent of the respondent beekeepers in Kathua district perceived training need of honey testing as the most important followed by method of wax production $(96.67 \%)$, supplying queen to queen less bees $(96.12 \%)$, feeding formula (93.79\%), honey processing 93.79\%, rearing of queen bees $93.02 \%$ and management of insect pests and diseases $(87.59 \%)$. The least perceived training need observed in the district include migration of boxes $(65.11 \%)$ followed by sugar feeding $(67.44 \%)$ and the uniting of boxes $(69.76 \%)$ as expressed by the respondent beekeepers and as per the calculated training need index.

Similarly based on the training need indices of Jammu district presented in Table 2 the data revealed that most important training need perceived by the beekeepers was honey testing $(100 \%)$ followed by management of insect pests and diseases (82.14\%) and method of wax production $(76.78 \%)$. The other importantly felt training needs reported were rearing of queen bee $(75.00 \%)$ followed by honey processing $(69.64 \%)$ and method of honey extraction $(66.07 \%)$. However, sugar feeding $(50.00 \%)$ and winter packing $(53.57 \%)$ were the least importantly perceived training needs of the respondent beekeepers.

Table.1 Training need of beekeepers of kathua district about apiculture practices $(n=43)$

\begin{tabular}{|c|c|c|c|c|c|c|}
\hline \multirow[t]{2}{*}{ Practice } & \multicolumn{3}{|c|}{ Beekeepers (\%) } & \multirow{2}{*}{$\begin{array}{l}\text { Actual } \\
\text { Score } \\
\text { obtained }\end{array}$} & \multirow{2}{*}{$\begin{array}{l}\text { Training } \\
\text { need index }\end{array}$} & \multirow[t]{2}{*}{ Rank } \\
\hline & $\begin{array}{c}\text { Most } \\
\text { needed (3) }\end{array}$ & $\begin{array}{l}\text { Needed } \\
\text { (2) }\end{array}$ & $\begin{array}{l}\text { Not needed } \\
\text { (1) }\end{array}$ & & & \\
\hline Honey testing & 100.00 & 0.00 & 0.00 & 129 & 100.00 & 1 \\
\hline Method of wax production & 93.02 & 6.98 & 0.00 & 126 & 97.67 & 2 \\
\hline Giving queen to queen less bees & 93.02 & 2.33 & 4.65 & 124 & 96.12 & 3 \\
\hline Formula of feeding & 83.72 & 13.95 & 2.33 & 121 & 93.79 & 4 \\
\hline Honey processing & 86.04 & 9.30 & 4.65 & 121 & 93.79 & 4 \\
\hline Rearing of queen bee & 83.72 & 11.63 & 4.65 & 120 & 93.02 & 5 \\
\hline Management of insect pests and disease & 69.77 & 23.25 & 6.98 & 113 & 87.59 & 6 \\
\hline Method of feeding & 69.77 & 6.98 & 23.25 & 106 & 82.17 & 7 \\
\hline Method of honey extraction & 69.77 & 6.98 & 23.25 & 106 & 82.17 & 7 \\
\hline Winter packing & 65.12 & 11.63 & 23.25 & 104 & 80.62 & 8 \\
\hline Division of boxes & 62.79 & 11.63 & 25.58 & 102 & 79.06 & 9 \\
\hline Training about bee flora throughout the year & 58.14 & 18.60 & 23.25 & 101 & 78.29 & 10 \\
\hline Uniting of boxes & 48.84 & 11.63 & 39.53 & 90 & 69.76 & 11 \\
\hline Giving sugar feeding & 48.84 & 4.65 & 46.51 & 87 & 67.44 & 12 \\
\hline Migration of boxes & 41.86 & 11.63 & 46.51 & 84 & 65.11 & 13 \\
\hline
\end{tabular}

Maximum score obtainable for each practice $=129$ 
Table.2 Training need of beekeepers of Jammu district about apiculture practices $(n=19)$

\begin{tabular}{|c|c|c|c|c|c|c|}
\hline \multirow[t]{2}{*}{ Practice } & \multicolumn{3}{|c|}{ Beekeepers (\%) } & \multirow{2}{*}{$\begin{array}{l}\text { Actual } \\
\text { score } \\
\text { obtained }\end{array}$} & \multirow{2}{*}{$\begin{array}{l}\text { Trainin } \\
\text { g need } \\
\text { index }\end{array}$} & \multirow[t]{2}{*}{ Rank } \\
\hline & $\begin{array}{c}\text { Most } \\
\text { needed (3) }\end{array}$ & $\begin{array}{l}\text { Needed } \\
\text { (2) }\end{array}$ & $\begin{array}{l}\text { Not needed } \\
\text { (1) }\end{array}$ & & & \\
\hline Honey testing & 94.73 & 5.26 & 0.00 & 56 & 100.00 & 1 \\
\hline Management of insect pests and disease & 47.37 & 47.37 & 5.26 & 46 & 82.14 & 2 \\
\hline Method of wax production & 31.58 & 63.15 & 5.26 & 43 & 76.78 & 3 \\
\hline Rearing of queen bee & 36.84 & 47.37 & 15.79 & 42 & 75.00 & 4 \\
\hline Honey processing & 36.84 & 31.58 & 31.58 & 39 & 69.64 & 5 \\
\hline Method of honey extraction & 26.32 & 42.10 & 31.58 & 37 & 66.07 & 6 \\
\hline Training about bee flora throughout the year & 21.05 & 52.63 & 26.32 & 37 & 66.07 & 6 \\
\hline Giving queen to queen less bees & 36.84 & 21.05 & 42.10 & 37 & 66.07 & 6 \\
\hline Uniting of boxes & 31.58 & 31.38 & 36.84 & 37 & 66.07 & 6 \\
\hline Formula of feeding & 15.79 & 52.63 & 31.57 & 35 & 62.50 & 7 \\
\hline Migration of boxes & 26.32 & 21.05 & 52.63 & 33 & 58.98 & 8 \\
\hline Method of feeding & 21.05 & 26.32 & 52.63 & 32 & 57.14 & 9 \\
\hline Division of boxes & 21.05 & 21.05 & 57.89 & 31 & 55.35 & 10 \\
\hline Winter packing & 15.79 & 26.32 & 57.89 & 30 & 53.57 & 11 \\
\hline Giving sugar feeding & 10.53 & 26.32 & 63.15 & 28 & 50.00 & 12 \\
\hline
\end{tabular}

Maximum score obtainable for each practice $=57$

Table.3 Training need of beekeepers of Rajouri district about apiculture practices $(n=22)$

\begin{tabular}{|c|c|c|c|c|c|c|}
\hline \multirow[t]{2}{*}{ Practice } & \multicolumn{3}{|c|}{ Beekeepers (\%) } & \multirow{2}{*}{$\begin{array}{l}\text { Actual } \\
\text { Score } \\
\text { obtained }\end{array}$} & \multirow{2}{*}{$\begin{array}{l}\text { Training } \\
\text { need } \\
\text { index }\end{array}$} & \multirow[t]{2}{*}{ Rank } \\
\hline & $\begin{array}{c}\text { Most } \\
\text { needed } \\
(3)\end{array}$ & $\begin{array}{l}\text { Needed } \\
\text { (2) }\end{array}$ & $\begin{array}{c}\text { Not } \\
\text { needed } \\
\text { (1) }\end{array}$ & & & \\
\hline Honey testing & 100.00 & 0.00 & 0.00 & 66 & 100.00 & 1 \\
\hline Management of insect pests and disease & 90.91 & 4.54 & 4.54 & 63 & 95.45 & 2 \\
\hline Rearing of queen bee & 86.36 & 9.09 & 4.54 & 62 & 93.93 & 3 \\
\hline Giving queen to queen less bees & 81.82 & 13.64 & 4.54 & 61 & 92.42 & 4 \\
\hline Migration of boxes & 77.27 & 18.18 & 4.54 & 60 & 90.90 & 5 \\
\hline Method of wax production & 63.64 & 36.36 & 0.00 & 58 & 87.87 & 6 \\
\hline $\begin{array}{l}\text { Training about bee flora throughout the } \\
\text { year }\end{array}$ & 59.09 & 36.36 & 4.54 & 56 & 84.84 & 7 \\
\hline Honey processing & 59.09 & 36.36 & 4.54 & 56 & 84.84 & 7 \\
\hline Formula of feeding & 45.45 & 45.45 & 9.09 & 52 & 78.78 & 8 \\
\hline Winter packing & 45.45 & 36.36 & 18.18 & 50 & 75.75 & 9 \\
\hline Method of feeding & 45.45 & 31.82 & 22.73 & 49 & 74.24 & 10 \\
\hline Method of honey extraction & 45.45 & 31.82 & 22.73 & 49 & 74.24 & 10 \\
\hline Division of boxes & 45.45 & 22.73 & 31.82 & 47 & 71.21 & 11 \\
\hline Uniting of boxes & 45.45 & 22.73 & 31.82 & 47 & 71.21 & 11 \\
\hline Giving sugar feeding & 36.36 & 27.27 & 36.36 & 44 & 66.66 & 12 \\
\hline
\end{tabular}

Maximum score obtainable for each practice $=66$ 
Table.4 Training need of beekeepers of Ramban district about apiculture practices(n=126)

\begin{tabular}{|c|c|c|c|c|c|c|}
\hline \multirow[t]{2}{*}{ Practice } & \multicolumn{3}{|c|}{ Beekeepers (\%) } & \multirow{2}{*}{$\begin{array}{l}\text { Actual } \\
\text { Score } \\
\text { obtained }\end{array}$} & \multirow{2}{*}{$\begin{array}{l}\text { Training } \\
\text { need index }\end{array}$} & \multirow[t]{2}{*}{ Rank } \\
\hline & $\begin{array}{c}\text { Most } \\
\text { needed (3) }\end{array}$ & $\begin{array}{l}\text { Needed } \\
\text { (2) }\end{array}$ & $\begin{array}{l}\text { Not needed } \\
\text { (1) }\end{array}$ & & & \\
\hline Honey testing & 64.28 & 35.72 & 0 & 333 & 100 & 1 \\
\hline Rearing of queen bee & 55.55 & 30.16 & 14.28 & 304 & 91.29 & 2 \\
\hline $\begin{array}{l}\text { Management of insect pests and } \\
\text { disease }\end{array}$ & 42.86 & 49.21 & 7.93 & 296 & 88.88 & 3 \\
\hline Method of wax production & 51.58 & 30.16 & 18.25 & 294 & 88.28 & 4 \\
\hline Honey processing & 41.27 & 44.44 & 14.28 & 286 & 85.88 & 5 \\
\hline Giving queen to queen less bees & 40.47 & 34.13 & 25.4 & 271 & 81.38 & 6 \\
\hline Formula of feeding & 34.92 & 38.09 & 26.98 & 262 & 78.67 & 7 \\
\hline Method of honey extraction & 35.72 & 31.74 & 32.53 & 256 & 76.87 & 8 \\
\hline Division of boxes & 32.54 & 35.72 & 31.74 & 253 & 75.97 & 9 \\
\hline $\begin{array}{l}\text { Training about bee flora } \\
\text { throughout the year }\end{array}$ & 26.19 & 46.83 & 26.98 & 251 & 75.37 & 10 \\
\hline Migration of boxes & 31.74 & 31.74 & 36.51 & 246 & 73.87 & 11 \\
\hline Winter packing & 25.4 & 42.86 & 31.74 & 244 & 73.27 & 12 \\
\hline Uniting of boxes & 35.72 & 31.74 & 32.53 & 237 & 71.17 & 13 \\
\hline Giving sugar feeding & 29.36 & 26.19 & 44.44 & 233 & 69.96 & 14 \\
\hline Method of feeding & 23.81 & 31.74 & 44.44 & 226 & 67.86 & 15 \\
\hline
\end{tabular}

Maximum score obtainable for each practice $=333$

Table.5 Training need of beekeepers of Jammu region about apiculture practices $(n=210)$

\begin{tabular}{|c|c|c|c|c|c|c|}
\hline \multirow[t]{2}{*}{ Practice } & \multicolumn{3}{|c|}{ Beekeepers (\%) } & \multirow{2}{*}{$\begin{array}{l}\text { Actual } \\
\text { Score } \\
\text { obtained }\end{array}$} & \multirow{2}{*}{$\begin{array}{l}\text { Training } \\
\text { need } \\
\text { index }\end{array}$} & \multirow[t]{2}{*}{ Rank } \\
\hline & $\begin{array}{c}\text { Most } \\
\text { needed (3) }\end{array}$ & $\begin{array}{l}\text { Needed } \\
(2)\end{array}$ & $\begin{array}{l}\text { Not needed } \\
\text { (1) }\end{array}$ & & & \\
\hline Honey testing & 78.09 & 21.90 & 0.00 & 584 & 100.00 & 1 \\
\hline Rearing of queen bee & 62.86 & 25.71 & 11.43 & 528 & 90.41 & 2 \\
\hline Method of wax production & 59.52 & 29.05 & 11.43 & 521 & 89.21 & 3 \\
\hline Management of insect pests and disease & 53.81 & 39.05 & 7.14 & 518 & 88.69 & 4 \\
\hline Honey processing & 51.90 & 35.24 & 12.86 & 502 & 85.95 & 5 \\
\hline Giving queen to queen less bees & 55.24 & 24.28 & 20.47 & 493 & 84.41 & 6 \\
\hline Formula of feeding & 44.28 & 35.24 & 20.47 & 470 & 80.47 & 7 \\
\hline Method of honey extraction & 42.86 & 27.62 & 29.52 & 448 & 76.71 & 8 \\
\hline $\begin{array}{l}\text { Training about bee flora throughout the } \\
\text { year }\end{array}$ & 35.71 & 40.47 & 23.81 & 445 & 76.19 & 9 \\
\hline Division of boxes & 39.05 & 28.09 & 32.86 & 433 & 74.14 & 10 \\
\hline Winter packing & 34.76 & 34.28 & 30.95 & 428 & 73.28 & 11 \\
\hline Migration of boxes & 38.09 & 25.24 & 36.66 & 423 & 72.43 & 12 \\
\hline Method of feeding & 35.24 & 26.19 & 38.57 & 413 & 70.71 & 13 \\
\hline Uniting of boxes & 37.62 & 20.47 & 41.90 & 411 & 70.37 & 14 \\
\hline Giving sugar feeding & 32.38 & 21.90 & 45.71 & 392 & 67.12 & 15 \\
\hline
\end{tabular}

Maximum score obtainable for each practice $=630$ 
Similar trend was observed in district Rajouri while calculating the training need index as presented in Table 3. The results revealed that the beekeepers of Rajouri district also perceived the honey testing as the most important training requirement as hundred per cent beekeepers responded positively followed by management of insect pests $(95.45 \%)$, rearing of queen bee $(93.93 \%)$, giving queen to queen less boxes $(92.42 \%)$ and migration of boxes $(90.90 \%)$ and method of wax production (87.87\%). Uniting and division of boxes recorded similar training need index of $71.21 \%$ followed sugar feeding $(66.66 \%)$ and were also perceived amongst the important training needs of beekeepers.

The district Ramban which holds the maximum beekeepers in the region also recorded the maximum training need index in case of honey testing as almost 100 per cent of beekeepers perceived the training need in this practice followed by rearing of queen bee $(91.29 \%)$, management of insect pests $(88.88 \%)$, method of wax production $(88.28 \%)$, honey processing $(85.88 \%)$ and giving queen to queen less bees $(81.38 \%)$. However, the uniting of boxes, giving sugar feeding and method of feeding also perceived the important training need status as these practices also recorded a training need index of 71.17, 69.96 and 67.86 per cent respectively as observed by the respondent apiculturists (Table 4).

The pooled data regarding the perception of training needs of different beekeeping practices for beekeepers of the region revealed that honey testing was perceived as most important on the basis of the training need index calculated for the practice as cent per cent of the beekeepers responded positively for requirement of the training followed by queen rearing $(90.41 \%)$, method of wax production $(89.21 \%)$, management of insect pests $(88.69 \%)$, honey processing
(85.95\%) and giving queen to queen less bees (84.41) as depicted in Table 5. The other bee keeping practices like honey extraction, bee flora, division of boxes and winter packing were also perceived amongst the important training needs by the respondent beekeepers as observed by the training need index. However, the feeding method (70.71\%), uniting of boxes $(70.37 \%)$ and sugar feeding (67.12) were perceived amongst the less important training needs of the respondent beekeepers.

A well constructed, valid and reliable knowledge test is a better method of finding the training needs of the farmers in general and beekeepers in particular. The main idea of training is to develop adequate level of working knowledge in any profession including beekeeping. Training is the critical input for human resource development. It plays an important role in initiating and accelerating human behaviour. Training being a tool for making interventions at the level of human resource is increasingly becoming crucial for development in almost all fields with growing satisfaction in technology. In order to make any training more meaningful and contributing, it is imperative on the part of organizer, to identify the training needs of trainees (Singh et al., 2011).

The increase in knowledge and adoption of scientific beekeeping practices offers a means to increase the honey production and generate income and employment for the rural youth. Beekeeping is a professionally specialized job and requires knowledge about scientific aspects of bee keeping practices like bee biology, bee flora, bee enemies, management of insect pests and disease, bee breeding, production of honey and other bee products, marketing besides general and seasonal management aspects. Therefore, knowledge is an important factor of production besides land, labour and capital. During the present 
study it was observed that the maximum percentage of beekeepers in all the districts possessed knowledge and general information about common bee keeping practices but lack the scientific aspects of these practices. Therefore, present study was undertaken to know the thrust areas where the training need is mostly perceived by the beekeepers. The training needs were determined by administering rating scale about the self perceived training needs of the beekeepers. The training needs of beekeepers were identified on the basis of training need indices calculated with respect to scientific beekeeping practices. The study emphasized on different agencies to develop specialized scientific training modules for beekeepers on bee biology, honey testing, management of bee enemies, insect/mite pests and diseases, production technology of honey and other bee products, bee breeding, bee flora, seasonal management, marketing, etc, instead of conducting generalized trainings.

The present study revealed that majority of the beekeepers perceived training need on honey testing because presently to check purity and differentiate between pure and adulterated honey is a critical issue in marketing in order to fetch a better price for the product. The other practices in which the beekeepers perceived a dire need for training include rearing of queen bee, management of bee enemies, insect/mite pests and diseases, honey processing, giving queen to queen less bees. The results were found in conformity with the findings of Chittaranjan et al., 2006; Singh et al., 2010); Singh et al., 2011 and Lal et al., 2012).

On the basis of training needs perceived by the respondent beekeepers of Jammu region, it was concluded that maximum beekeepers of Ramban district perceived training needs of scientific apiculture practices followed by beekeepers of Kathua, Rajouri and Jammu districts. Honey testing, rearing of queen bee, method of wax production and management of bee enemies, insect/mite pests and diseases were observed the important thrust areas in which beekeepers require training as the calculated training need indices were observed higher in comparison to other practices. Moreover, the beekeepers perceived least training need in method of feeding, uniting of boxes and sugar feeding. Keeping in view the present studies the government should select the thrust areas in apiculture practices on the basis of training need and involve the professionally sound extension personnel and apiculture wing of Department of Agriculture, SKUAST- Jammu and other NGOs in imparting training throughout the Jammu province.

\section{References}

Anonymous, 1999. Agriculture status of $J \& K$ state. Directorate of Agriculture department, Government of Jammu and Kashmir.

Anonymous, 2001. Agricultural Statistics at a Glance. Directorate of Economics and Statistics, Ministry of Agriculture, Government of India.

Chittaranjan, D., Neog, P.K., Das, M.D. 2006. Level of knowledge of the participants of training programme conducted by AAU, under AICRP on honey bee on recommended practices of scientific beekeeping. Journal of Interacademicia, 10(4): 596-599.

Lal, R., Sharma, S.D., Sharma, J.K., Sharma, V. and Singh, D. 2012. Impact of beekeeping training on socioeconomic status of farmers and rural youths in Kullu and Mandi Districts of Himachal Pradesh. J Hum Ecol, 39 (3):205-208.

Singh, B., Gatoria, G.S. and Chuneja, P.K. 2007. Selection of best performing Apis mellifera colonies for stock 
improvement programme. Indian bee Journal, 69(1/4): 1-7.

Singh, K. 2005. Evaluation of the agricultural vocational training courses conducted by KVKs in Punbab. Ph.D thesis, P.A.U, Ludhiana, Punjab.

Singh, K., Peshin, R. and Saini, K.S. 2010. Evaluation of the agricultural vocational training programmes conducted by the Krishi Vigyan Kendras (Farm Science Centres) in India Punjab. Journal of Agriculture and Rural Development in the Tropics and Subtropics, vol.111 No.2, 65-77.

Singh, K.C. and Singh, C.J. 2003. Training needs of women entrepreneur in rural area of Madhya Pradesh. JNKVVResearch Journal, 37(2): 52-55.

Singh, K.V., Singh, G.P. and Priyadarshi, A. 2010. Extent of Adoption of Improved Practices of Mango Production by
Mango Growers in Muzaffarnagar District of Uttar Pradesh, Indian Research Journal of Extension Education. 10(3).

Singh, M., Mishra, S. and Rani, S. 2001. Training needs of rural women. Indian Journal of Extension Education, Vol.xxxvii No.1 \&2, pp92-94.

Singh, N., Yadav, V.P.S., Raina, V. and Chand, R. 2011. Training Needs of Bee Keepers of Haryana. Indian Research Journal of Extension Education, 11(1), Jan.

Singh, R. 1975. On optimum stratification for proportional allocation. Sankhya 37: 109-115.

Soumya P S and Podikunju B (2017). Effect of training on knowledge and adoption of value addition technology. . Journal of Krishi Vigyan. 5 (2):57-59.

\section{How to cite this article:}

Yogesh Kumar, Kaneez Fatima, Rajinder Peshin' Bashir A Rather, Sushil Kumar and Mehrajuddin Sofi. 2020. Training Need Perception of Beekeepers with Respect to the Scientific Beekeeping Practices in Jammu Province. Int.J.Curr.Microbiol.App.Sci. 9(09): 3172-3179. doi: https://doi.org/10.20546/ijcmas.2020.909.392 